\title{
Marigold dream, maternal nightmare
}

I mages of Nepal haunt me. Marigolds held in the hands of old men walking along village paths to devotions at corner shrines; marigolds left at these shrines crushed and the bitter scent drifting; huge banks of marigolds, beyond them distance and space in the clear thin air of high altitude, before them, simple homes under an expansive blue sky.

Thin curling wisps of smoke from wood fires intermingle with the cold clear mountain air. To keep these wood fires fed, women, bent almost double, walk with huge loads of firewood on their backs. During our 6-hour hike into one of the health project villages that received Canadian support, we saw these women, so burdened, as we carried nothing save an umbrella.

The valley below this mountain road looked like Shangri La. But was it? Suddenly we heard drumming and chanting and moved aside to clear a path for a procession of men coming toward us. One by one they emerged from around the bend, following the leader who played a mournful drum.

There was a hush. Then we saw the bier: the draped, red-cloth-covered body of a fully pregnant woman who had died in labour at term. This was her funeral procession. It wound slowly downhill from us, around to the next bend: a circular procession marking a lost life. The drumming faded away as the last person rounded the corner and vanished from sight, disturbing the sandy dusty soil as he passed.

We stood still, silent, humbled.

As health professionals we "knew" that statistically a woman here has a I in 2 chance of dying in labour.

Among the UN Millennium Development Goals, the least progress is being made with maternal health. The goal, set in 2000, is to reduce maternal mortality $75 \%$ from its 1990 value by 2015 (see page 243). In 2004, the UN Development Programme estimated a maternal mortality ratio of 740 per 100 ooo live births in Nepal; the Population Reference Bureau pegged it even higher at
830. In sub-Saharan Africa, where the maternal mortality ratio is the world's highest (920 per 100 ooo live births), there has been negligible improvement in skilled attendance at delivery (rising from $42 \%$ to just $46 \%$ ); South Asia has only improved from $30 \%-36 \% .{ }^{1}$ Getting back on track to achieving these goals will require primary heatlh care interventions, stronger clinical services and greater resources. ${ }^{2}$ But we also need to deal with women's low status, which limits their reproductive choices, their access to nutritious food and basic health services.

During our visit to Nepal, we saw and understood the myriad causes of maternal mortality, including weak family planning, restricted access to abortion, the lowest skilled attendance at delivery in South Asia, high rates of adolescent childbearing and few emergency obstetric care services.

These are the facts. It was shattering to confront the reality; to see it. In Nepal, we saw a I2-year-old girl in an arranged marriage who was frightened but trusting. Her hips were too small for childbearing, it was an obstructed labour and no one had the skill or equipment to do the cesarean section. Though trained to do sections, many doctors fear reprisals if they make a mistake and quickly lose these skills through lack of practice.

Then there was the much older husband who wouldn't allow his young wife to leave home for a hospital delivery even though she was hemorrhaging in labour, because she had to feed the water buffalo. "Her duty is to stay here. If she dies it is fated and I will get a new wife and a new dowry." The wife didn't question him.

And there was the case of a woman who didn't want another child, but whose husband insisted on the pregnancy, hoping for a son instead of a fourth unwanted daughter. In desperation she resorted to a clandestine abortion and arrived dying at hospital in septic shock having travelled hours by ox-cart. She arrived too late, there were not enough antibiotics to save her. Half

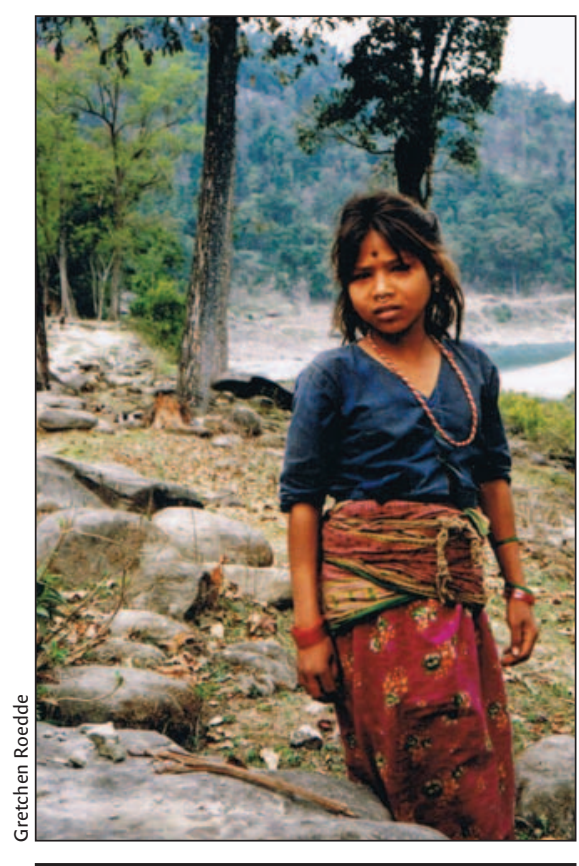

This married 12-year-old Nepalese woman faces a high risk of maternal death.

of the maternal deaths in hospitals in Nepal are due to unsafe abortion.

We talked to women who eat less during pregnancy, hoping for a smaller baby and easier delivery, who eat least and last in any case, and who are so anemic at delivery that any excessive blood loss leads to death. Other women told us they ate soil during pregnancy. "We are hungry. Our husbands say we already have something in our bellies, so they take what food there is, and we must eat soil to fill our hunger."

Time and despair conspires. The vast distance between what should be done and what can be done in my lifetime.

\section{Gretchen Roedde MD}

Family physician

International reproductive health care consultant

Temiskaming Shores, Ont.

\section{REFERENCES}

I. The millennium development goals report. New York: United Nations; 2006.

2. Evans D, Lim S, Adam T, et al. Evaluation of current strategies and future priorities for improving health in developing countries. BMJ 2005;331:1457-61. 